4. Архангельский Г.И. Холерные эпидемии в Европейской России в 50-летний период 1823-1872 гг. СПб., 1874. 504 с.

5. Эрисман Ф.Ф. Руководство к гигиене. СПб., 1877. $201 \mathrm{c}$

6. Губернские ведомости // Энциклопедический словарь Брокгауза и Ефрона. СПб.: Брокгауз-Ефрон, 1890-1907.

7. Любичанковский С.В. Местное управление в пореформенной России: механизмы власти и их эффективность. Сводные материалы заочной дискуссии. Российская академия наук, Поволжский филиал Института Российской истории РАН. ЕкатеринбургИжевск, 2010. 498 с.

8. Военно-медицинский журнал // Энциклопедический словарь Брогауза и Ефрона. СПб.: БрокгаузЕфрон, 1889.

9. Минх Г.Н. Проказа на юге России 1884-1887. М.: Типография императорского университета Св. Владимира, 1890. 233 с.

10. Ковнер С.Г. История средневековой медицины. Киев: Типография императорского университета Св. Владимира, 1893. 623 с.

11. Заболотный Д.К. Чума, эпидемиология, патогенез и профилактика // Заболотный Д.К. Избранные труды. Киев: АН УССР, 1956. 205 с.
12. Бароян О.В. Итоги полувековой борьбы с инфекциями в СССР и некоторые актуальные вопросы современной эпидемиологии. М.: Медицина, 1968. 304 с.

13. Громбах С.М. Данило Самойлович. Жизнь и деятельность. М., 1952.52 с.

14. Миленушкин Ю.И. Выдающийся деятель отечественной медицины Д.К. Заболотный. М.: Знание, 1954. $152 \mathrm{c}$.

15. Васильев К.Г. Д.К. Заболотный (1866-1929). М.: Медицина, 1986. 102 с.

16. Билай В.И. Жизнь, отданная людям. Киев: Наукова думка, 1966.84 с.

17. Блинкин С.А. В борьбе с инфекциями. М.: Медицина, 1971. $168 \mathrm{c}$.

18. Васильев К.Г. История эпидемий и борьба с ними в России в ХX столетии. М.: Медгиз, 1960. $397 \mathrm{c.}$

19. Супотницкий М.В., Супотницкая Н.С. Очерки истории чумы. М., 2006. 964 с.

20. Арнаутова Ю.Е. Колдуны и святые: Антропология болезни в Средние века. СПб.: Алетейя, 2004. $400 \mathrm{c}$.

21. Богданов К.А. Врачи, пациенты, читатели: Патографические тексты русской культуры XVIIIХІХ веков. М.: ОГИ, 2005. 504 с.

\title{
THE EPIDEMIOLOGICAL STATUS OF THE RUSSIAN EMPIRE: HISTORY OF RESEARCH IN DOMESTIC SCIENCE AND PRACTICE
}

\author{
D.M. Mifteeva, postgraduate student of the Chair of history of Russia \\ Orenburg State Pedagogical University, Orenburg (Russia)
}

Abstract. This article discusses the history of the study of epidemic diseases in domestic science, analyses the main tendencies of epidemiology as a science in Russia. The importance of the work of scientists - practitioners is the fight against infectious diseases in previous centuries, the positive experience which is the basis of modern science of epidemiology. This fight against infectious diseases in previous centuries had mixed results. On the one hand, domestic and foreign epidemiologists outstanding results have been achieved in the treatment and prevention of infectious diseases, which allowed significantly reduce of the morbidity and mortality rates in the XX-XXI centuries. At the same time, the history of the modern period is characterized by a set of social and economic changes: the growth of cities, the intensity of migration, transformation also affected the age structure of the population of the world. All these factors have led to a change in one of the main characteristics of the majority of infectious diseases - the limited territorial localization in the XXI century. It is observed the tendency of spread of epidemics to a considerable distance, they become global. New and unknown diseases such as SARS, swine and bird flu (H1N1 and H5N1), Ebola virus, the middle east respiratory syndrome (MERS), etc. arise at this time. It is registered the return of liquidated infections: typhoid, cholera, yellow fever, etc. These processes show that humanity is still a long way to complete victory over infectious diseases, and to study the experience achieved in the previous century scientists - epidemiologists. They would make a significant contribution in the unequal struggle with the human virus.

Keywords: infectious diseases; the epidemiological situation; environmental factor; epizootic; territorial localization; domestic historiography; Russian empire; old Russian chronicles; control measures; public policy; our medicine; plague; cholera; pox; malaria; historical experience; spread; microbiology; prevention.

УДК 94(47)"1800"

\section{ПАВЛОВСКИЙ СЕНАТ И ВОПРОС О ПОДАТНОМ СТАТУСЕ МЕЛКОЙ ШЛЯХТЫ ЗАПАДНЫХ ГУБЕРНИЙ НА РУБЕЖЕ ХVIII-XIX ВЕКОВ}

(C) 2016

К.В. Трояновский, аспирант департамента истории

Санкт-Петербургская школа соииальных и гуманитарных наук

Наџионального исследовательского университета «Высшая школа экономики», Санкт-Петербург (Россия)

Аннотация. После разделов Речи Посполитой перед новыми властями встала проблема определения статуса мелкой шляхты в сословной иерархии Российской империи. На рубеже XVIII-XIX вв. этот вопрос решался 
в Сенате. В апреле 1800 г. по представлению 3-го департамента Сената, Павел I подтвердил фискальный иммунитет мелкой шляхты и другие привилегии, которыми она пользовалась в Речи Посполитой. Однако в том же году после рассмотрения частного вопроса о налогообложении шляхты, оказавшейся в Новороссийской губернии, 1-й департамент Сената принял две резолюции, противоречащие смыслу апрельского постановления.

В статье анализируются обстоятельства принятия департаментами Сената решений, которые отразили разные подходы к проблеме включения малоимущего нобилитета западных губерний в состав высшего сословия Российской империи. Постановление 3-го департамента предполагало кооптацию целой группы посредством законодательного признания ее привилегированного статуса. В основе резолюций 1-го департамента лежала установка на интеграцию в ряды российского дворянства каждого шляхтича в индивидуальном порядке. В итоге предпочтение было отдано второй модели, по которой принадлежность к шляхте должна была регулироваться в соответствии с российскими законами.

Ключевые слова: Российская империя; Павел I; западные губернии; «польские» губернии; имперская сословная политика; Сенат; сенаторы; департаменты Сената; сословия; социальный статус; сословные права и привилегии; дворянство; мелкая шляхта; А.И. Васильев; Л.С. Ворцель; Т. Козловский; О.Г. Кутлубицкий (Котлубицкий); П.Х. Обольянинов.

В результате второго и третьего разделов Речи Посполитой 1793-1795 гг. Российская империя приобрела обширные территории с населением в несколько миллионов человек. Одной из главных особенностей исчезнувшего Польско-Литовского государства была многочисленность его привилегированного сословия - шляхты, которая составляла в середине XVIII столетия, по принятым в современной историографии оценкам, 8-10\% всего населения [1, c. 4]. К 1796 г. в пределах империи проживало свыше 250 тысяч шляхтичей [2, с. $158,163,164]$. Польское дворянство представляло собой конгломерат различных по своему имущественному положению социальных групп. Значительное большинство дворян старой Польши, превратившихся в подданных российских монархов, принадлежали к мелкой шляхте, которая собственным трудом добывала средства к существованию. Наиболее многочисленной категорией была «чиншевая» шляхта, которая по договоренности с помещиками владела и обрабатывала небольшие участки земли, платя в качестве ренты условленную денежную сумму («чинш»).

Изучение истории дворянства Речи Посполитой, в т.ч. и мелкой шляхты, оказавшегося по итогам разделов в пределах Российской империи, занимает важное место в современной историографии Белоруссии, Литвы, Польши, Украины. Однако обстоятельства появления на повестке дня в Петербурге вопроса о месте мелкой шляхты в сословной иерархии Российской империи рассматриваются лишь в немногих работах. Справедливо считая 1800 год важной вехой, когда было положено начало правительственным мерам по «разбору» шляхты (т.е. определению ее сословной принадлежности), историки внимательно анализируют содержание указов, предписывавших шляхте представить доказательства своего дворянства, спорят о датах их издания. Хотя еще в 1990 г. И. Рыхликова опубликовала сведения об изданных в июне и сентябре 1800 г. в отношении шляхты двух указах [3, p. 110-112], историки продолжают приводить разные данные по датировке и количеству этих указов $[4$, с. 103,$161 ; 5$, с. $27-28 ; 6$, с. $87 ; 7$, с. 127 , 130].

При исследовании имперской политики в отношении шляхты на рубеже XVIII и XIX веков большинство исследователей рассматривают Сенат как цельный, консолидированный орган высшего государственного управления, игнорируя то обстоятельство, что сенатские департаменты действовали как самостоятельные органы и в рамках своей компетенции принимали резолюции и издавали указы от имени всего Правительствующего Сената. Возможно, именно такое понимание функционирования Сената помешало историкам обратить должное внимание на противоречащие друг другу резолюции, принятые его 3-м и 1-м департаментами и воплощенные в соответствующих указах 12 апреля и 15 июня 1800 г. Вместе с тем некоторые исследователи отмечают «непоследовательность политики» [4, с. 102] и «противоречия» $[6$, с. 87] по вопросу об обложении мелкой шляхты подушной податью.

Задачей настоящей статьи является анализ обстоятельств рассмотрения в Сенате вопроса о податном статусе мелкой шляхты в годы царствования Павла I, а также резолюций и указов Сената, принятых по этому поводу в 1800 г.

Воцарение Павла, считавшего разделы Польши несправедливым актом [8, с. 219], создало благоприятные условия для законодательного закрепления за шляхтой ее прежнего статуса. В отличии от Екатерины II, стремившейся к унификации новых территорий с имперским центром, Павел I стал с уважением относиться к традиционным судебно-правовым структурам на окраинах [9, с. 387, 388]. 12 декабря 1796 г. монарх объявил о том, что Белорусская, Виленская, Волынская, Гродненская, Киевская, Минская и Подольская губернии (в дореволюционной историографии они обозначались как «польские» или «западные»; в данной работе эти термины используются в качестве конвенции для обозначения административно-территориальных единиц Российской империи, образованных из бывших земель Речи Посполитой), наряду с остзейскими и малороссийскими, а также Выборгской, должны находится «на особых по правам и привилегиям их основаниях» [10, с. 229]. На этих пограничных территориях были созданы аналоги прежних судебных учреждений, сохранены исторически сложившиеся системы права и процессуальные нормы судопроизводства, существовавшие там до присоединения к России.

Особое положение этих областей институционально было воплощено в 3-м департаменте Сената, который со времени реформы 1763 г. являлся для них высшей апелляционной инстанцией $[11$, с. $463 ; 12$, c. 388]. На рубеже XVIII и XIX вв. в нем решались и некоторые вопросы администрирования, в частности, 
вопросы по разъяснению порядка организации дворянских выборов в «польских» губерниях [13, л. 1]. Территории, приобретенные в ходе разделов Польши, также были отнесены к его ведению. Решение дел, поступающих из судов этих губерний, требовало от сенаторов департамента специального знания местных правовых норм. Именно этим объясняется то обстоятельство, что от трети до половины его членов в разные годы на рубеже XVIII и XIX веков составляли представители региональных элит - выходцы из остзейских и «польских» губерний. В павловское время среди сенаторов этого департамента были помещики Курляндии и Лифляндии - бароны Карл Генрих фон Гейкинг, Бальтазар Иоганн фон Кампенгаузен, Отто Герман фон дер Ховен (Говен), граф Готхард Андреас фон Мантейфель, владельцы обширных имений в западных губерниях - графы Лев (Леонард) Ворцель, Август Илинский, Северин Потоцкий, и др. [14, с. 94, 107, 116, 186, 193, 266]. 3-й департамент Сената стал тем государственным институтом управления, с помощью которого представители западных окраин империи отстаивали интересы своих губерний на основе старых привилегий, подтвержденных Павлом І. Именно это обстоятельство часто становилось причиной разногласий между представителями пограничных и внутренних губерний империи. Бывший в 1796-1798 гг. сенатором 3-го департамента Г.К. фон Гейкинг в своих воспоминаниях «обрисова [л] дух партийной розни, царившей тогда ... между старинными русскими и новоприобретенными провинциями» $[15$, с. 9-10, 20-21]. Русский поэт и писатель И.И. Дмитриев, служивший в 1797-1798 гг. обер-прокурором этого департамента, в своих воспоминаниях также отмечал «разномыслие» между «русскими сенаторами», с одной стороны, и Гейкингом, Ховеном и Илинским, с другой [16, c. 139-141].

Однако к январю 1800 г., когда в 3-й департамент по распоряжению Павла I поступило дело, в котором затрагивался вопрос о положении мелкой шляхты, среди его членов уже не было ни П.А. Соймонова, которого К.Г. фон Гейкинг называл «диктатором», пытавшимся при поддержке русских сенаторов игнорировать местное право при решении дел из остзейских губерний [15, с. 9, 20-21], ни самого Гейкинга, который будучи президентом юстиц-коллегии лифляндских, эстляндских и финляднских дел стоял на страже старых привилегий. Видимо, отсутствие среди сенаторов департамента противников особого правового статуса пограничных областей свело на нет противостояние между «русской» и «немецко-польской» группами. В январе-марте 1800 г., когда рассматривался вопрос о шляхте, из сенаторов департамента заседания посещали Л.С. Ворцель, Б.Б Кампенгаузен, О.П. Козодавлев (обер-прокурор 3-го департамента в 1796-1797 гг.). А.И Илинский, А.И. Голохвастов, Д.П. Трощинский были командированы царем для ревизии губерний, гр. И.А. Безбородко был в отпуске, О.О. фон дер Говен и С.Ф. Стрекалов отсутствовали по болезни. Обер-прокурором департамента с декабря 1799 г. являлся А.Н. Оленин (в будущем известный государственный деятель) [17, л. 1-845].

Вопрос о сословном статусе мелкой шляхты в империи возник как следствие инвентаризации челове- ческих и материальных ресурсов завоеванных территорий, которая была проведена в ходе 5-й ревизии 1795-1796 гг. и люстрации (хозяйственного описания и кадастра имений, принадлежавших в прошлом польской короне) 1798-1800 гг. [18, с. 187-189] в западных губерниях. Ревизия здесь прошла по особым правилам, разработанным генерал-губернатором Т.И. Тутолминым. В качестве отдельных категорий населения, которые пользовались «преимуществами благородных», помимо других привилегированных классов учету подлежали чиншевые, околичные и служебные шляхтичи. Однако они вписывалась не в ревизские сказки (предназначенные исключительно для податного населения), а в «особые именные ведомости» по каждому населенному пункту [19, с. 234, 235]. Таким образом, мелкая шляхта с различными наименованиями была документально зафиксирована как особая сословная категория империи.

Люстрация государственных имений в новоприсоединенных областях вызвала появление проектов по увеличению с них доходов. Один из таких проектов содержался в донесении статского советника И. Кутлубицкого, поданого на «высочайшее» имя в конце 1799 г. (Иосиф (Осип Григорьевич) Кутлубицкий (Котлубицкий) был отцом Николая Кутлубицкого, генерал-лейтенанта свиты Павла I и коменданта Михайловского замка. Источники сведений И. Кутлубицкого для составления проекта неизвестны. Судя по формулярному списку, И. Кутлубицкий поступил в 1767 г. в Киеве на российскую службу по линии иностранных дел; владея восточными языками, во время русско-турецких войн исполнял различные поручения главнокомандующих армиями. Ему принадлежали 38 крепостных в Черниговской губернии [20, л. 3 об. $-4,5])$.

В проекте описывались способы получения для казны до двух млн. рублей дополнительных доходов в Киевской, Подольской и Волынской губерниях. Речь шла главным образом о старостинских имениях (т.е. принадлежавших ранее польской короне), доходы с которых незаконно присваивались их временными владельцами. Говоря об упускаемых казной выгодах, Кутлубицкий упоминал и о 100-тысячной безземельной шляхте, которая вынуждена была «сносить от помещиков непомерные угнетения без всякой казенной пользы, платя им чинш». Если же поселить этих шляхтичей в казенных имениях, то, по мнению автора записки, «до 500000 рублей они согласятся платить подати и, сверх того, к составлению войска могут с пользою употреблены быть ...» [21, л. 126-126 об.; 22, с. 351]. Очевидно, эти предположения Кутлубицкого отражали обсуждавшиеся в Петербурге планы использования в государственных целях потенциала мелкой шляхты как лично свободного населения.

К концу марта 1800 г. в отношении плана Кутлубицкого, переданного в Сенат, 3-й департамент подготовил доклад, который был представлен Павлу I на утверждение [17, л. 624 об]. Предложение провести на месте расследование о сообщаемых злоупотреблениях было одобрено департаментом. Однако пункт о переселении шляхты на старостинские земли и обложении ее податями сенаторы отвергли. В отношении 
мелкой шляхты доклад содержал положение, имевшее весьма важное значение для определения ее правового статуса. В нем указывалось, что шляхта была «всегда то же, что и дворяне, и из них безземельная шляхта для снискания себе пропитания нанимают от другой своей собратии излишние земли по контрактам и платят им не с особ, а с земли, или за домы ими нанимаемые. А потому за силою конституций 1374 , 1457, 1463, 1699 и 1768 годов, увольняющих шляхетство от всех податей, [они] не могут никакой подлежать перемене их преимуществ» [21, л. 127 об.128 об.; 22, с. 351-352]. Здесь обращают на себя внимание два момента: во-первых, в соответствии с политической традицией Речи Посполитой безземельная шляхта представлялась как совершенно равная в своих правах помещикам и магнатам; и во-вторых, ссылаясь на польские законы, актуальность которых для западных губерний была подтверждена Павлом I, сенаторы пытались закрепить в российском законодательстве особые права шляхты (вне зависимости от ее имущественного положения) как де-факто высшего сословия в западных губерниях.

12 апреля 1800 г. доклад 3-го департамента был утвержден императором [17, л. 752 об.-753 об; 21, л. 125-129]. Можно высказать предположение, что важную роль в подготовке доклада и включении в него положения о мелкой шляхте сыграл сенатор Л.С. Ворцель - единственный представитель «польских» губерний, который присутствовал на всех заседаниях этого департамента во время рассмотрения плана Кутлубицкого [17, л. 85, 192, 368 об., 624 об., 658 об.]. Инициатива Ворцеля была направлена на разрешение вопроса о статусе мелкой шляхты в благоприятном для нее отношении. Учитывая признание верховной властью империи прежних привилегий польских областей, эта правовая норма могла привести к сохранению в них традиционной сословной структуры.

Следует сказать, что 3-й департамент незадолго до этого уже выносил по другому делу резолюцию, подтверждавшую старые привилегии мелкой шляхты еще в одном отношении. В феврале 1800 г. исполнявший обязанности «маршала» (предводителя) дворянства одного из уездов Подольской губернии Каэтан Пешинский обратился в Сенат с представлением о разрешении участвовать в дворянских выборах мелкопоместным шляхтичам. В качестве обоснования он ссылался на практику Речи Посполитой и приводил ряд польских конституций, санкционировавших участие такой шляхты в сеймиках. Апелляция к шляхетским привилегиям Речи Посполитой была с полным пониманием встречена в 3-м департаменте. 19 марта 1800 г. был издан указ, по которому на основании конституции 1768 г. разрешалось допускать к выборам всех «природных дворян», имеющих во временном пользовании помещичьи и казенные имения. Допускались даже их братья и другие родственники, не имеющие таких владений, но принадлежащие к древним родам [23, л. 13-13 об.]. (Этот указ не вошел в Полное собрание законов и в историографии о нем известно только из указа Александра I от 8 июня 1802 г.: [24, с. 159]. См.: [25, s. 153, fn. 27]).

В тот же день - 12 апреля 1800 г., когда Павел I утвердил доклад 3-го департамента, в 1-м департа- менте Сената, ведавшим административными и фискальными делами в масштабах всей империи, был заслушан вопрос об обложении подушным окладом находившейся в Новороссийской губернии мелкой шляхты. Этот вопрос ждал своего решения с начала 1797 г. Дело в том, что в результате административно-территориальных изменений часть бывших польских земель (входивших в 1793-1794 гг. в Брацлавскую губернию) была передана в состав образованной в начале 1795 г. Вознесенской губернии (наместничества) [26, с. 641-644]. В январе 1797 г. Вознесенская казенная палата донесла Сенату о том, что во время проведения 5-й ревизии возник вопрос о «положении в оклад» чиншевой шляхты. В Чигиринском уезде на требование полиции подать ревизские сказки шляхтичи, не имевшие на руках документов о своем происхождении, через предводителя дворянства попросили правителя наместничества кн. П.Н. Оболенского не записывать их «в оклад» до подачи доказательств в уездные дворянские комиссии. В качестве уважительной причины они ссылались на то обстоятельство, что документы находятся у их родственников заграницей - в Австрии и Пруссии. Тем не менее, Оболенский в октябре 1796 г. распорядился вносить таких людей в ревизские сказки для обложения подушной податью, но с пометкой о том, что «они объявили себя шляхетством и имеют представить на дворянское их достоинство доказательства» [27, л. 3-4]. Оболенский следовал указаниям своего начальника екатеринославского, вознесенского и таврического генерал-губернатора кн. П.А. Зубова. Еще в мае 1795 г. Зубов предписал местной администрации «при устроении вообще губернии Вознесенской» иметь в виду указ Екатерины II от 3 мая 1795 г. на имя Т.И. Тутолмина [27, л. 4-4 об]. Этим указом позволялось «всем по договорам, на землях помещичьих или казенных живущим, которые могут надлежащим образом доказать благородство свое», просить «общество дворянское о принятии и вписании ... в дворянскую книгу, дабы каждый ... мог воспользоваться правами сему достоинству присвоенными, во вступлении в службу нашу и в приобретении имения» [28, c. 694-695]. Поскольку действие этого указа распространялось на все присоединенные от Польши земли, то, по мнению Зубова, его следовало применить и к уездам, отошедшим от Брацлавской губернии к Вознесенской. Исходя из указа, Зубов запретил вписывать в дворянскую книгу «под названием околичной и чиншевой шляхты» тех просителей, которые не смогут представить доказательств. Такие лица должны были быть причислены к «поселянам ведомства нижних расправ» [27, л. 3-6]. Примечательно, что даже после административно-территориальных изменений, в результате которых образовалась губерния, включавшая в себя территории как бывшей Речи Посполитой, так и Турции, и Крымского ханства, Зубов вводил в ней для местной шляхты особый правовой режим на пространстве, очерченном границами старой Польши.

Поскольку в «польских» губерниях с чиншевой шляхты взыскание податей не производилось, а в указе 3 мая 1795 г. и предписании Зубова ничего не говорилось о ее податном статусе, Вознесенская казенная палата запросила Сенат о разрешении на об- 
ложение не представивших доказательств шляхтичей податями «наравне с поселянами казенного ведомства». В присоединенных к Вознесенской губернии семи «польских» уездах насчитывалось 9833 «душ мужеска пола» такой шляхты [27, л. 3-6, 7-16 об.].

После ликвидации Вознесенского наместничества неразрешенное дело о шляхте перешло в Новороссийскую казенную палату, от имени которой вицегубернатор П.И. Неверовский в апреле 1799 г. направил новый запрос в Сенат о том, «в каком звании причисляющихся в сию губернию полскую чиншовую шляхту считать, и следует ли их какою податью обложить?» [27, л. 17-18 об]. Поводом к этому послужила просьба от живущих в Киевской губернии двух шляхтичей о причислении их в казенные поселяне в Новороссийском уезде. На основе запроса палаты сенатская экспедиция, контролировавшая налоговые поступления, по указанию государственного казначея А.И. Васильева подготовила записку, которая была представлена Сенату [27, л. 1-2 об.]. Заслушав ее в сентябре 1799 г., 1-й департамент Сената не принял в тот момент никакого решения и вернулся к рассмотрению вопроса только 12 апреля 1800 г., то есть в день конфирмации Павлом I доклада 3-го департамента, подтверждавшего привилегии шляхты.

Была ли между этими событиями связь? По всей вероятности, доклад 3-го департамента представлял монарху генерал-прокурор П.Х. Обольянинов, назначенный на эту должность в феврале 1800 г. Последующий ход событий показывает, что только входивший в курс дел Обольянинов не обратил тогда должного внимания на положение о привилегиях мелкой шляхты. (Игравший в павловское время важную роль в работе канцелярии генерал-прокуроров М.М. Сперанский считал, что «всех их менее имел способностей Обольянинов и ему все с рук сходило» [29, c. 64]). В докладе, озаглавленном «О возложении местного исследования о доносимой статским советником Котлубицким потери дохода до 2-х миллионов рублей на комиссии, учрежденные для производства новой люстрации» [17, л. 752 об.; 30, л. 166 об.-167], норма о шляхте выглядела как частность и была явно не на первом плане. Тем не менее упоминание шляхты в докладе могло напомнить чиновникам канцелярий генерал-прокурора или 1-го департамента о запросе из Новороссийской губернии.

Еще одной причиной появления вновь на повестке дня 1-го департамента вопроса о налогах со шляхты в Новороссии послужил проект переселения чиншевой шляхты из Киевской и Подольской губерний в смежную с ними Новороссийскую губернию. Его автор упомянутый выше вице-губернатор Неверовский, 16 марта 1800 г. направил соответствующее представление генерал-прокурору [31, л. 4-5 об.]. В пользу этого предположения говорит то обстоятельство, что именно 12 апреля 1800 г. генерал-прокурор передал это представление на рассмотрение в Экспедицию государственного хозяйства [31, л. 3].

1-й департамент уже сталкивался с проблемой определения сословного статуса некоторых шляхтичей западных губерний, поскольку в его ведомстве находилась Герольдия, занимавшаяся рассмотрением доказательств дворянства. В своих решениях Сенат воплощал политику Павла I, который с самого начала своего царствования занял жесткую позицию в вопросах признания в дворянстве [32, с. 461-465]. Указом от 4 декабря 1796 г. монарх запретил дворянским собраниям и другим губернским учреждениям «вводить» кого-либо в дворянство и выдавать соответствующие грамоты [33, с. 216-217]. В развитие этого указа 19 марта 1797 г. было постановлено, что собрания могут только выносить свои заключения о полноте подаваемых просителями доказательств, которые должны были затем отсылаться в Петербург на окончательное решение Герольдии. Таким образом, фактически было отменено одно из главных положений Жалованной грамоты дворянству, согласно которому дворянское собрание каждой губернии имело право признавать просителей дворянами на основе представленных ими доказательств.

Опасения Павла I были вызваны тем, что губернские собрания не слишком придирчиво подходили к рассмотрению доказательств и признавали в дворянстве даже таких просителей, которые были записаны в ревизские сказки. Еще в 1789 г. Сенат распорядился присылать в Герольдию списки состоявших в подушном окладе лиц, которые тем не менее были признаны во дворянстве губернскими собраниями [34, c. 39-40]. Особенно остро эта проблема проявилась в Белорусской губернии, где множество потомков служилых людей, считавших себя шляхтичами, были записаны крупными помещиками в ревизские сказки [3, p. 122-127]. Доказавшие дворянство в губернских собраниях, каковых к 1800 г. насчитывалось 1096 «душ», требовали исключения из подушного оклада. В ответ на просьбы некоторых из них 9 апреля 1800 г. 1-й департамент Сената предписал губернским властям неукоснительно выполнять предыдущие указы и представлять доказательства о дворянстве таких лиц в Герольдию. Сенат отмечал, что эти люди, имея на руках грамоты о дворянстве из губернских собраний, уклоняются от податей и повинностей, считая себя законными дворянами. Поэтому до утверждения их в дворянстве Герольдией и самим императором, они должны были оставаться в подушном окладе [35, c. 128-130]. Таким образом, у 1-го департамента были серьезные сомнения в том, действительно ли шляхтичей-землепашцев можно отнести к «благородному» сословию.

Представляется также, что мнение, высказанное П.А. Зубовым в ходе 5-й ревизии на юге империи о принадлежности мелкой шляхты к нижним классам населения, было принято во внимание сенаторами при рассмотрении вопроса о ее статусе. Очевидно, что Зубов считался экспертом в делах, связанных с Польшей (Зубов ведал и докладывал императрице «дела польские» [36, с. 206, 220]). В 1796 г. Екатерина II одобрила проект своего фаворита о переселении в Вознесенскую губернию нескольких тысяч семей мелкой шляхты для колонизации южного края и создания из них «поселенных полков». Зубов отождествлял беспоместную шляхту «польских» губерний с российскими однодворцами [37, с. 897-900]. Подобное сопоставление изначально формировало у русских сановников, мало или совсем не знакомых с общественным строем Речи Посполитой, определенные стереотипы и соответствующее отношение к мелкой шляхте. 
Вновь рассмотрев 23 апреля 1800 г. представления казенных палат южного края, 1-й департамент Сената своим определением установил двухгодичный срок, начиная с 1 января 1800 г., для подачи доказательств о своем дворянском происхождении чиншевыми и околичными шляхтичами, проживающими в Новороссийской губернии. В течение этого срока было предписано взыскивать с них все государственные подати, которые государство обещало вернуть тем из них, кто будет утвержден в дворянстве «высочайшею» властью. Непредставившие до 1 января 1803 г. доказательств должны были быть «положены в оклад наравне с казенными поселянами». Двух же шляхтичей по их просьбе Сенат разрешил причислить в казенные поселяне [27, л. 19-21]. Несомненно, что прошения о приписке к крестьянам также повлияли на решение сенаторов об обложении шляхты подушным налогом. С точки зрения сановников, если шляхта действительно являлась дворянами, было невозможно объяснить желание двух шляхтичей перейти в низшее сословие.

Это решение выглядело как продолжение курса по ограничению доступа в дворянское сословие. Следует иметь также в виду, что в 1-м департаменте не было ни одного представителя окраин - там заседала в основном старомосковская аристократия - кн. Г.П. Гагарин, кн. Н.Б. Юсупов, гр. Н.Н. Головин, бар. А.И. Васильев, П.С. Свистунов, Ф.А. Колокольцев [14, c. $100,124,390,506]$, которые не спешили признавать мелкую шляхту за российских дворян. Кроме того, среди сенаторов 1-го департамента помимо государственного казначея Васильева были главы экономических ведомств, формировавших доходы государства, - Гагарин с 1798 г. был президентом Коммерцколлегии, а Юсупов с 1797 г. возглавлял Мануфактур-коллегию [38, с. 166-167, 890-891]. Эти сановники в силу своих должностных обязанностей должны были блюсти «казенный интерес» особенно тогда, когда в условиях острого бюджетного дефицита империя нуждалась в новых источниках дохода. Определение от 23 апреля также вполне отражало политику павловского времени по увеличению податного населения за счет новых категорий, прежде свободных от повинностей [8, с. 429].

Государственный казначей и сенатор А.И. Васильев, будучи по должности главным блюстителем интересов фиска, посчитал правомерным вскоре поставить вопрос о налогообложении уже всей шляхты западных губерний. 20 июля 1800 г. Васильев представил в 1-й департамент Сената новую записку. (По наблюдениям А.Э. Нольде, «едва ли не большая часть» сенатских указов в павловское время, вошедших в ПСЗ, состоялись по представлениям Васильева $[12$, c. 748$])$. Упомянув о решении Сената в отношении мелкой шляхты Новороссийской губернии, Васильев сообщал, что по данным финансового ведомства «подобной и разной сверх того шляхты», которая «не положена в оклад» в западных губерниях находится 218025 душ мужского пола. Представляя ведомость о численности разных групп шляхтичей по губерниям, Васильев просил Сенат вынести резолюцию и о них $[27$, л. $28-28$ об.]. Докладчик и готовившие записку чиновники имели слабое представление о реалиях бывших польских земель. Это хорошо иллюстрирует- ся тем, что в ведомость помимо разных категорий мелкой шляхты, которая, как раз, и рассматривалась как объект для налогообложения, были включены по некоторым губерниям «дедичные владельцы» (т.е. помещики), «поссесоры» (арендаторы имений), а также другие категории населения, не относящиеся к шляхте [27, л. 29-29 об.].

Рассмотрев 17 августа записку Васильева, департамент принял в отношении указанных в ведомости разных категорий «неположенной в оклад» шляхты точно такую же резолюцию как и о живущих в Новороссийской губернии. Шляхта должна была, начиная с 1 января 1800 г., в течении двух лет подать в дворянские собрания доказательства о своем дворянстве. На протяжении этого времени она облагалась государственными податями «наравне с казенными поселянами» тех губерний. Не представившие доказательств в течении установленного срока, должны были остаться на положении казенных крестьян [27, л. 30-32]. Указ об исполнении первой резолюции был послан новороссийским властям 15 июня 1800 г. Но поскольку он повлек неожиданные для властей последствия, указ по второй резолюции послан так и не был.

Итак, 1-й департамент Сената 23 апреля и 17 августа принял две резолюции о взымании подушной подати с недоказавшей дворянства шляхты, которые по своей сути противоречили утвержденному 12 апреля Павлом I докладу 3-го департамента, в котором подтверждался ее фискальный иммунитет. Для объяснения подобной коллизии, скорее всего, следует предположить, что этот документ остался незамеченным как в канцелярии генерал-прокурора, так и в 1-м департаменте вопреки системе внутренних информационных потоков в Сенате. Подлинники сенатских докладов, адресованных монарху, обычно передавались с его резолюцией в Общее собрание Сената для оглашения. Не должен был быть исключением и апрельский доклад. Кроме того, 3-й департамент после отсылки указов с копией доклада в западные губернии 26 апреля передал копию со своего определения «К генерал-прокурорским делам» [30, л. 166 об.-167, 173]. Тем не менее возможности того, что сенатские чиновники оставались в неведении нормы о шляхте нельзя исключить ввиду перегруженности и общего состояния дел в Сенате в павловское время. (А.Э. Нольде писал о «хаотическ [ом] беспорядк [е]» в Сенате при Павле I $[12$, с. 728$])$. О том, что 1-й департамент не располагал информацией об апрельском постановлении свидетельствует тот факт, что в ответе на запрос о чиншевой шляхте, присланном 4 мая 1800 г. из канцелярии 1-го департамента Сената в Экспедицию государственного хозяйства, доклад 3-го департамента не упоминался [31, л. 13]. Для предположения же об умышленном противодействии со стороны сенаторов норме, утвержденной самим царем, не имеется достаточных оснований. Хорошо зная крутой нрав Павла I, сановники не стали бы рисковать своим положением из-за своей убежденности в том, что неимущая шляхта не достойна дворянского звания.

На просчеты в работе всего сенатского аппарата и 1-го департамента, в частности, указывает и следующее обстоятельство. К моменту разрешения дела о 
шляхте в 1-м департаменте образованные из бывших польских территорий уезды уже три года как были переданы из упраздненной Вознесенской в Киевскую и Подольскую губернии [39, с. 706-710]. Это само по себе должно было снять вопрос с повестки дня, однако 1-й департамент не учел этого обстоятельства.

Получив сенатский указ от 15 июня, Новороссийская казенная палата переслала его в Киев и КаменецПодольский [27, л. 23-24]. Киевский губернатор А.Г. Теплов, имея в виду полученный из 3-го департамента Сената указ о сохранении шляхетских привилегий, не решился сделать распоряжения к исполнению нового указа. 9 августа Теплов обратился к генералпрокурору за разъяснением. Застигнутый, похоже, врасплох, П.Х. Обольянинов 4 сентября поручил оберпрокурору 3-го департамента Оленину собрать справки о шляхте и подготовить выдержки из польсколитовских законов о ее правовом статусе [40, л. 1].

Тем временем по Киевской губернии стали распространяться слухи о предстоящем обложении шляхты подушной податью. Указ Сената был истолкован таким образом, что подати должны будут платить не только те шляхтичи, которые живут в четырех уездах (переданных из Вознесенской), но в пределах всей Киевской губернии. Губернскому предводителю дворянства Тадеушу Козловскому удалось тайно получить копию сенатского указа, присланного из Новороссийской палаты [40, л. 13-13 об., 14-14 об.]. В конце августа и сентябре он обращался к Теплову, убеждая его ходатайствовать об отмене указа. Умело разыграв карту непредсказуемых политических последствий, которые могут произойти от обложения мелкой шляхты «обесчестивающей» (в оригинале письма: «un payment deshonorant» [40, л. 43 об.]) подушной податью, Козловскому удалось вызвать тревогу по поводу безопасности в крае у петербургских «верхов». Намек на существование там «якобинцев» [40, л. 44-44 об.] задел тонкие струны страхов Павла I, постоянно опасавшегося внутренних социальных потрясений [41, с. 482].

Как представляется, основными мотивами киевского «маршала» для предпринятия такого демарша были как опасения за судьбу всех представителей бывшего привилегированного сословия Речи Посполитой, ныне ставших подданными непредсказуемого российского монарха, так и желание сохранить для польских помещиков те выгоды, которые они получали от мелкой шляхты, платившей им чинш, служившей в «экономиях» и т.п. Возможно также, что интрига вокруг мелкой шляхты была лишь способом для польской региональной элиты дискредитировать план Кутлубицкого, в котором она видела попытку покушения на свои права владеть бывшими коронными имениями.

Во многом благодаря интриге Т. Козловского вопрос о статусе мелкой шляхты был быстро пересмотрен в Сенате. 25 сентября 1800 г. 1-й департмент направил в губернские правления всех западных губерний новый указ, в котором требование к шляхте представить доказательства своего «благородного» происхождения сопровождалось более мягкими условиями, а угроза обложения подушной податью не фигурировала. В указе цитировалось постановление 3-го департамента от 12 апреля о сохранении за шляхтой старых привилегий и даже сеймовая конституция 1374 г. Согласно новому указу, для подачи шляхтой доказательств о дворянском происхождении устанавливался двухгодичный срок, начиная с 1 января 1801 г. В течение этого времени шляхтичи сохраняли свой прежний статус и не подвергались налогам и повинностям. По истечении срока местные власти должны были собрать и представить в Сенат сведения обо всех лицах, которые не представили документы. Особо было сказано о том, что указ о шляхте от 15 июня остается в силе для Новороссийской губернии, где шляхта должна быть обложена подушной податью [27, л. 33-39 об.; 40, л. 15-18]. По рапортам Новороссийских губернских властей, после изменения границ в их губернии осталось только 16 шляхтичей [27, л. $23-24,25-25$ об.].

Подводя итог, следует сказать, что разрешение в Сенате вопроса о фискальном статусе мелкой шляхты западных губерний было принципиально значимым для определения ее правового положения, поскольку именно подушная подать маркировала непривилегированные группы населения в империи [42, р. 21]. Департаменты Сената, в которые независимо друг от друга поступили дела, связанные с этим вопросом, приняли в 1800 г. противоречащие одно другому решения. Утверждение императором доклада 3-го департамента Сената, согласно которому вся шляхта in corpore признавалась равной дворянам, могло положить начало институализации шляхты в качестве особого сословия империи с привилегированным статусом. Решение же 1-го департамента, которым от шляхты были потребованы письменные доказательства ее «благородного» происхождения, перечисленные в Жалованной грамоте дворянства 1785 г., фактически означало, что имперская власть не признает особого сословного статуса мелкой шляхты и на бывшие польские области должен распространяться институт общеимперского дворянства. По сути решения департаментов Сената предполагали разные модели включения шляхты в социальную структуру империи: кооптацию целой группы путем законодательного признания ее привилегированного статуса или интеграцию в ряды российского дворянства каждого шляхтича в индивидуальном порядке (в случае представления доказательств, соответствующих требованиям имперского законодательства). Предпочтение было отдано второй модели, по которой принадлежность к шляхте должна была регулироваться в соответствии с российскими законами.

\section{СПИСОК ЛИТЕРАТУРЫ:}

1. Кабузан В.М., Троицкий С.М. Изменения в численности, удельном весе и размещении дворянства в России в 1782-1858 гг. // История СССР. М., 1971. № 4. С. 153-169.

2. Rostworowski E. Ilu było w Rzeczypospolitej obywateli szlachty? // Kwartalnik Historyczny, rocznik XCIV, 1988. No. 3. P. 3-39.

3. Rychlikowa I. Tatarzy litewscy 1764-1831 częścią szlacheckiego stanu? // Kwartalnik Historyczny. R. XCVII. Z. 3-4. Warszawa, 1990. P. 77-120.

4. Бовуа Д. Гордиев узел Российской империи: Власть, шляхта и народ на Правобережной Украине (1793-1914) / Авторизован. пер. с фр. М.А. Крисань. М.: Новое литературное обозрение, 2011. 1008 с. 
5. Лисенко С., Чернецький Є. Правобережна шляхта: кінець XVIII - перша половина XX ст. Біла Церква: Видавець О.В. Пшонківський, 2007. 448 с.

6. Макарэвіч В. «Цяжкі разбор» - фармаванне і рєалізацыя палітыкі «разбору» шляхты ў беларускалитоўскіх і ўкраінскіх губернях Расійскай імперыі ў 1796-1811 гг. // Białoruskie Zeszyty Historyczne, 43. Białystok, 2015. C. 83-102.

7. Туміловіч Г. Расійскі царызм і шляхта Беларусі (1795-1863) // Беларускі гістарычны агляд. Т. 17. Сшыткі 1-2 (32-33). Снежань, 2010. С. 125-153.

8. Скоробогатов А.В. Политические взгляды Павла I: Становление, эволюция, реализация. дис. ... д-ра ист. наук. М., 2005. 524 с.

9. Каппелер А. Россия - многонациональная империя. Возникновение, история, распад / Пер. с нем. С. Червонная. М.: Традиция, Прогресс-Традиция, 2000.344 c.

10. Полное собрание законов Российской Империи. Собрание Первое. 1649-1825 гг.: в 45 тт. СПб.: Тип. II отделения Собственной его императорского величества канцелярии, 1830 (далее - ПС3-1). № 17634 . Т. 24.

11. ПСЗ-1. Т. 16. № 11989.

12. История Правительствующего Сената за двести лет, 1711-1911. СПб., 1911. Т. 2. 806 с.

13. Российский государственный исторический архив (далее - РГИА). Ф. 1347. ОП. 64. Д. 347 (О выборах в Подольской губернии).

14. Мурзанов Н.А. Словарь русских сенаторов 1711-1917. Материалы для биографий / Изд. подгот. Д.Н. Шилов. СПб.: Дмитрий Буланин, 2011. 735 с.

15. Гейкинг К.Г. Дни императора Павла: Записки курляндского дворянина / Пер. с нем. СПб.: Ф.И. Булгаков, 1907. 70 с.

16. Дмитриев И.И. Взгляд на мою жизнь: Записки действительного тайного советника Ивана Ивановича Дмитриева: В 3 ч. / Предисловие М. Дмитриева, примечания М.Н. Лонгинова. М.: Изд. М.А. Дмитриев, $1866.315 \mathrm{c}$.

17. РГИА. Ф. 1347. Оп. 282. Д. 18 (Журналы 3-го департамента Сената. 9 января-30 апреля 1800 г.).

18. ПСЗ-1. Т. 25. № 18475.

19. Сборник документов, касающихся административного устройства Северо-западного края при императрице Екатерине II (1792-1796) / Предисловие А. Турцевич. Вильна: Виленская комиссия для разбора древних актов, 1903. $352 \mathrm{c.}$

20. РГИА. Ф. 1343. Оп. 23. Д. 7866 (О дворянстве Котлубицких).

\section{THE SENATE UNDER PAUL I AND THE ISSUE OF FISCAL STATUS OF PETTY SZLACHTA IN THE RUSSIAN WESTERN PROVINCES AT THE TURN OF THE $19^{\text {TH }}$ CENTURY}

(C) 2016

\section{(C) 2016}

\author{
C.V. Troianowski, postgraduate student of the Department of History \\ Saint Petersburg School of Social Sciences and Humanities \\ of National Research University «Higher School of Economics», Saint Petersburg (Russia)
}

21. РГИА. Ф. 1347. Оп. 282. Д. 23 (Определения 3го департамента Сената. 2 апреля-31 мая 1800 г.).

22. Имеретинский Н.К. Дворянство Волынской губернии // Журнал министерства народного просвещения. 1893. № 8. С. 343-368.

23. РГИА. Ф. 1347. Оп. 64. Д. 347 (О выборах по Подольской губернии).

24. ПСЗ-1. Т. 27. № 20288.

25. Ganzenmüller J. Russische Staatsgewalt und polnischer Adel. Elitenintegration und Staatsausbau im Westen des Zarenreiches (1772-1850). Köln: Böhlau Verlag Köln Weimar Wien, 2013. 425 p.

26. ПС3-1. . Т. 23. № 17300. 27.01.1795. С. 641.

27. РГИА. Ф. 1341. Оп. 1. Д. 346а (О шляхте в губерниях, от Польши присоединенных. Т. 1).

28. ПСЗ-1. Т. 23. № 17327.

29. Корф М.А. Жизнь графа Сперанского. СПб.: Императорская публичная библиотека, 1861. Т. 1. c.

30. РГИА. Ф. 1347. Оп. 281. Д. 159 (Книга исходящим указам за 1800 г.).

31. РГИА. Ф. 1286. Оп. 1.1802 г. Д. 108 (По представлению новороссийского вице-губернатора о переселении чиншевой шляхты из Киевской и Подольской губерний на пустопорожние земли, в Новороссийской губернии лежащие).

32. Клочков М.В. Очерки правительственной деятельности времени Павла I. Петроград: Сенат. тип., 1916. 631 с. (Записки Историко-филологического факультета Петроградского университета. Ч. 132).

П. ПС3-1. Т. 24. № 17608 .

36. Курукин И.В. Платон Зубов - «министр всех частей правления»: фаворитизм на исходе XVIII столетия // Quaestio Rossica. 2015. № 3. C. 200-226.

37. ПСЗ-1. Т. 23. № 17469.

38. Шилов Д.Н., Кузьмин Ю.А. Члены Государственного совета Российской империи. 1801-1906: Биобиблиографический справочник. СПб.: Дмитрий Буланин, 2006. 992 с.

39. ПС3-1. Т. 24. № 18117.

40. РГИА. Ф. 1347. Оп. 64. Д. 299 (О чиншевой шляхте).

41. Каменский А.Б. От Петра I до Павла I: Реформы в России XVIII века (опыт целостного анализа). М.: РГГУ, 1999. 575 c.

42. Freeze G.L. The Soslovie (Estate) Paradigm and Russian Social History // American Historical Review, 1986. Vol. 91. No. 1. (February 1986). P. 11-36.

Abstract. After the partitions of the Polish-Lithuanian Commonwealth in 1795 the Russian empire faced a problem of determining the social status of petty Polish nobles (szlachta) in imperial hierarchy. At the turn of the $19^{\text {th }}$ century the Senate was the governmental body that had to resolve this issue. In April of 1800 Paul I approved the proposal of the Senate's $3^{\mathrm{d}}$ department to confirm lesser szlachta's fiscal immunity and other privileges enjoyed by her under 
Rzecz Pospolita. Yet, in the same year the Senate's $1^{\text {st }}$ department when deliberating on a separate case of szlachta's tax status in Novorossiysk province, passed two resolutions that contradicted the legal norm adopted in April.

This paper focuses on the analysis of circumstances under which the Senate's departments came to different decisions on the same problem. Their resolutions reflected two approaches to the policy of petty szlachta's inclusion in the imperial nobility. The resolution of the $3^{\mathrm{d}}$ department, supported by Paul I, envisaged a co-optation of szlachta as a social group through legislative confirmation of its privileged status in the empire. The approach of the $1^{\text {st }}$ department emphasized the necessity of szlachta's integration into imperial nobility on the individual basis (by submitting proofs of noble origin compliant to the Russian laws). As a result the imperial government gave preference to the second model of inclusion.

Keywords: Russian empire; Paul I; lands of partitioned Poland; western borderlands; the Senate; departments of the Senate; senators; imperial politics; social estates (sosloviia); nobility; szlachta; social status; fiscal privileges; J. Kutlubicki (Kodlubicki); P. Obolianinov; T. Kozlowski; A. Vasiliev; L. Worcell.

\title{
УДК 908
}

\section{ИСТОРИЧЕСКИЕ ТРАНСФОРМАЦИИ СВОЕОБРАЗИЯ ГОРОДОВ САМАРСКОЙ ГУБЕРНИИ ВО ВТОРОЙ ПОЛОВИНЕ ХІХ ВЕКА}

(C) 2016

Ю.В. Корнеева, кандидат исторических наук, доцент кафедры туризма и гостиничного дела Поволжский государственный университет сервиса, Тольятти (Россия)

\begin{abstract}
Аннотация. Проблема исторического становления городов в последнее время весьма актуальна. Вторая половина XIX века - реформаторский этап российской истории, во время которого происходило переосмысления многих ценностей. Данный исторический период стал периодом индустриализации и урбанизации, благодаря которому провинциальные города получили свое новое развитие и процветание. Статья посвящена историческому развитию и преобразованию городов Самарской губернии во второй половине XIX века. Каждый город Самарской губернии за исследуемый период прошел свой уникальный путь развития и внес вклад в становление неповторимости региона. Своеобразие городов характеризуется с двух сторон: экономической и социальной. Экономическая уникальность городов Самарской губернии во второй половине века выражалась в таких показателях, как объемы промышленного производства и развитости торговых связей, которые для губернии выражались в разнообразии мест и форм торговли: ярмарки, железнодорожные станции и водные пристани. Социальная составляющая самобытности уездных городов региона формировалась из характеристик население: численность, сословная иерархия, менталитет. И каждый такой элемент формировал не только уникальность уездных городов, но и создавал общий единый облик индустриальной России.

Ключевые слова: город; Самарская губерния; вторая половина ХІХ века; городское население; урбанизация; индустриализация; промышленность; ярмарки; водные пристани; экономическое развитие; аграрные отношения; мещане; купцы; сельское население; городской менталитет; Самара.
\end{abstract}

Город как объект научного исследования в последнее время стал интересен многим учёным из различных областей знаний, историческая наука не стала исключением. Исследователи-историки изучают город как многостороннюю систему взаимоувязанных элементов. Такая система не только открыта к разного рода веяниям, но и развивается за счет различных составляющих элементов. Для существования и развития города государству необходимо обеспечить его в первую очередь людьми, финансами и информацией.

С возникновением городов и развитием городской жизни тесно связаны многие процессы переходного периода от первобытности к классовому обществу. Образование городов, пригородов, сел и прочих общественных поселений происходило по ряду причин. Главная из которых заключалась «в защите против неприятелей» [1, с. 377]. Первоначально даже само понятие «город» означало огороженное место, что было равносильно ограде. На основании этого местности для укрепления представляли больше надежды на безопасность в случае внешних нападений, и эти местности тщательно ограждались [1, с. 378].

Большинство славянских городов представляли собой укрепленные места для обороны от неприятелей. Причем, основные приемы их постройки были строго определены обычаями, фиксирующими эту необходимость. Леса вокруг городов представляли собой особое укрепленное пространство («засечные полосы»), затруднявшее перемещение даже для пешеходов. Обилие лесов и правильная организация управления дали возможность славянам обеспечить охрану и защиту, что способствовало устойчивому развитию их городов.

Итак, первые города являлись опорными пунктами обороны, местом сосредоточения княжеских властей и свободных соседских общин ремесленников и купцов. Это стимулировало развитие в городах монументальной архитектуры, создание памятников письменности и др.

Основным отличительным носителем городской жизни являлось население городов. «Первые горожане» представляли собой особый тип людей, который возник на базе промежуточных типов поселений, где были «представлены элементы патриархальной культуры, роднящие ее с деревней, и элементы «фабричной» культуры и мещанского фольклора, в которых чисто внешне присутствовали ценности крупных городов и их центров в первую очередь» [2, с. 42].

В России вторая половина XIX в. ознаменовалась рядом преобразований. Городская реформа Алек- 